\title{
What the NATO Alliance Is Currently Advocating and Delivering in the Counter Terrorism Arena ${ }^{1}$
}

\author{
Imre POGÁCSÁS²
}

\begin{abstract}
The fight against terrorism is still based on the nation-state framework, but international organizations have a greater focus on the prevention of terrorist acts. The European Union is not a military organization, it is involved mainly in prevention and combating crime and terrorism financing operations, and to resolve the consequences of an attack. In contrast, NATO is mainly focused on the fight against terrorism from a military perspective. It is important to emphasize that the fight against global terrorism can only be successful if comprehensive, international, multilateral action is taken, which includes military operations, in addition to political, economic, legal, diplomatic and social tools.

This analysis will seek to determine how those facts influence the NATO Counter Terrorism (CT) task and whether they are sufficient to justify making it a NATO core responsibility.
\end{abstract}

Keywords: terrorism-counter terrorism, global security, role for NATO, strategic and military concept, collective defence, international responsibilities

\section{Introduction}

The current NATO role is countering terrorism, showing how NATO could tackle the threat posed by worldwide terrorism today and what the Alliance is currently advocating and delivering in the Counter Terrorism arena. The events of $11^{\text {th }}$ September, 2001, launched a new phase in NATO's history, because after these terrorist attacks the Alliance implemented, for the first time, Article 5 of the Washington Treaty, in addition to a long-term NATO mission. This attack changed the international security environment and it brought a scope of challenges that the international community is still facing today.

In order to illustrate the main steps of the characteristics of NATO's fight against terrorism, we first need to define what we mean by terrorism. The word terrorism, originates from the French Revolution where the Jacobin dictatorship of terror used the term "régime de la Terreur", basically meaning the usage of violence and threats to intimidate or coerce, especially for political purposes. [1] Although the concept is not new, it still has no internationally accepted definition.

For the purpose of this analysis it is necessary to define terrorism and counter-terrorism. There are numerous definitions available, but the most relevant to NATO is the Military Committee Concept as follows:

1 The article based on the Author's Individual Research Paper, written at NATO Defence College in Rome.

2 Ph.D., Brig. Gen., Organizational Director of the Institute of Military Aviation; e-mail:pogacsas.imre@uninke.hu 
"Terrorism: The unlawful use or threatened use of force or violence, instilling fear and terror, against individuals or property in an attempt to coerce or intimidate governments or societies, or to gain control over a population, to achieve political, religious or ideological objectives.

Counter-Terrorism: All preventive, defensive and offensive measures taken to reduce the vulnerability of forces, individuals and property against terrorist threats and/or acts, to respond to terrorist acts. In the frame of the NATO Comprehensive Approach, this can be combined with or followed by measures enabling recovery after terrorist acts.” [2: 5]

Today terrorism is a major issue for the security of all NATO allies. The recent Paris, Brussels and Berlin events, terrorist attacks, showed that the world can no longer remain indifferent to terrorism. Terrorist groups seek to undermine state power, which includes the intimidation of the population. Their use of unpredictable and destructive practices threatens the sense of security; an ancient Chinese saying defines the essence of terrorism: "Kill one to warn a hundred”. [3]

Terrorism involves consideration of both international and domestic aspects. It affects energy security, critical infrastructure, maritime security, usage of Internet and cyberattacks, weapons of mass Destruction (WMD) and it has been connected with organized crime and narcotics related issues. [4]

The current threat is multipolar, unpredictable, in some cases invisible, and can be referred to as hybrid. "The concept of 'hybrid threats' is not new, nor is the idea that it conveys completely original-namely, the combination of conventional and unconventional methods of warfare so as to confuse an adversary.” [5: 1] The question is what is NATO's present and future contribution to the fight against terrorism, based on its current core tasks and strategy. How should NATO's role evolve better in order to counter terrorism?

\section{Where we are, what is the Role for NATO?}

Since 1949, the global security and international environment has constantly been changing. NATO has had to develop its strategy to adopt to major challenges by updating Strategic Concepts (SC) as follows: [6]

- 1949: just after creation of NATO;

- 1957: after Germany entered NATO;

- 1968: after France withdrew from military structures of NATO;

- 1991: after the Cold War ended;

- 1999: after the first-round enlargement to $\mathrm{CEEC}^{3}$ and the occasion of the $50^{\text {th }}$ anniversary of NATO;

- 2010: as a response to NATO enlargement since 1999.

The SC has been modified six times but the core tasks and principles for NATO do not list part CT as a core responsibility. Currently NATO's primary purpose is to defend the freedom and security of all its members by political and military means and it remains an essential source of stability for the Alliance. The current Strategic Concept adopted at the NATO Summit in Lisbon on 19-20 $0^{\text {th }}$ November, 2010, states that the Alliance will continue to effectively fulfill three essential core tasks: collective defence, crisis management, cooperative security. [7] All three tasks contribute to safeguarding Alliance members in accordance with international law.

3 CEEC (Central and East European Coalition) 
The SC clearly identified terrorism as a permanent growing threat for NATO's security. As a consequence, the Alliance decided to "enhance the capacity to detect and defend against international terrorism, including through enhanced analysis of the threat, more consultations with our partners, and the development of appropriate military capabilities, including helping training local forces to fight terrorism themselves.” [8: 17]

This means that CT is already a part of the Defence and Deterrence core task of NATO, but not explicitly stated.

\section{The evolution of NATO's response on CT}

Based on the title of this analysis we need to know how history shaped NATO's strategy to countering terrorism from 1999 to 2016. The 1999 SC defined terrorism as a risk affecting NATO's security but practical measures were not adopted by the Allies. Due to the terrorist attack in New York this changed, and NATO launched its first ever CT operation called Operation Eagle Assist. It was followed by a second CT operation, Active Endeavour, which was a maritime surveillance operation in the Mediterranean, together with anti-terrorist patrols and escort. [9] The next evolutionary step was the endorsement of the Prague-Package at NATO's 2002 Prague Summit, where the Alliance articulated their enhanced contribution to CT.

Following that NATO adopted a Military Concept for Defence Against Terrorism (DAT), that includes five nuclear biological and chemical defence initiatives, tasks for protection of civilian populations, together with Civil Emergency Planning Action Plan, as well as the NATO Response Force principles. [10]

At the 2004 Istanbul Summit the Alliance decided that collective defence remains their core purpose, even though the threats that NATO faces had changed significantly. NATO endorsed the creation of the DAT Programme of Work (POW) to develop its capability to tackle asymmetric threats. [11]

At the Riga NATO meeting in 2006, the Alliance strengthened their commitment to the Afghanistan mission and they also recognized that the military itself is not enough to create Afghanistan's long-term stability. [12] To emphasize it, Mr. de Hoop Scheffer, ${ }^{4}$ said at the meeting: "It is winnable, it is being won, but not yet won." [12]

Two years later in Bucharest the leaders of NATO continued the open-door policy and reaffirmed solidarity to ensure operational capability in Afghanistan. They also confirmed the implementation of Iraqi Security Forces. The Communiqué of this meeting covers "an agreement to work on the development of options for comprehensive missile defence architecture, the role of arms control, disarmament and non-proliferation, the importance of the NATO Response Force, the Alliance Ground Surveillance capability, a new policy on cyber defence, principles of the Allied approach to energy security and many others”, aside from CT. [13]

At the Lisbon Summit in 2010, the leaders of NATO member states adopted the alliance's new Strategic Concept, "that (is being) able to defend its members against the full range of threats”, determined NATO internal reform, agreed on the future operations in Afghanistan, and the creation of European missile defence. In addition, NATO's relationship with Russia was re-evaluated. [7] The 2010 Summit summarized as Active Engagement, Modern Defence is a very clear statement and vision with strategic objectives for the next decade.

4 NATO former Secretary General 
It states that collective defence, crisis management and cooperative security remain the Alliance's essential core tasks, even though the security environment has changed. [8: 7-17]

The Defence and Deterrence chapter of the Concept included the following activities related to CT: [8: 7-17]

- enhancing the capacity to detect and defend against international terrorism, with enhanced analysis of the threat;

- more consultations with NATO partners;

- developing appropriate military capabilities, including helping train local forces to fight terrorism themselves.

At the Chicago Summit in 2012, NATO agreed to continue counter-piracy Operation Ocean Shield, Operation Active Endeavour, which contributed to the fight against terrorism, and to a non-Article 5 Maritime Security Operation. It supported a strategic air and maritime lift for the African Union's (so called AU) Mission in Somalia (AMISOM). The NATO leaders also agreed to the development of the AU's long-term peacekeeping capabilities. Allies enhanced their commitment to fight terrorism with determination in connection with international law and the principles of the United Nations (UN) Charter and endorsed NATO's Policy Guidelines on CT to enhance NATO's ability to prevent, deter, and respond to terrorism. [14]

In connection with CT related issues the Wales Summit in 2014, discussed the Ukrainian crisis, the fight against the Islamic State of radical Islamist armed groups, the military future of the Alliance, defence spending amongst allies and the end of combat operations in Afghanistan. Due to the Ukrainian crisis, the Allies raised the level of contingency, and agreed to establish a Very High Readiness Joint Task Force that can deploy within a few days. In order to ensure that our Alliance is ready to respond to the new security challenges, they approved the NATO Readiness Action Plan as well. The Allies agreed to increase the defence budget and work towards the NATO guideline of spending 2\% of GDP on defence expenditure by 2020. Besides that, NATO decided that troops, were to remain in Afghanistan after 2015, even when they were drawing down forces to complete the ISAF (International Security Assistance Force) mission by $31^{\text {st }}$ December, 2014. [15]

The Wales Summit welcomed the extension of the mandate of the counter-piracy operation off the Horn of Africa. They reviewed strategic options for the future of Operation Active Endeavour as in the Article 5 maritime operation in the Mediterranean. This Summit had more intentions concerning Terrorism and CT than previous ones, because it separately dealt with countering the threat of ISIL/Daesh terrorism: "If the security of any Ally is threatened, we will not hesitate to take all necessary steps to ensure our collective defence.” [16: para 33] On the other hand, the fight against terrorism issue will continue to improve capabilities and technologies, including the defence against Improvised Explosive Devices and CBRN threats. NATO will keep terrorism and related threats high on the security agenda. [16: para 79]

NATO Allies have made two important decisions in connection with the terrorist threat and the alliance's action against terrorism at the 2016 Warsaw Summit. They extended the alliance's mission in Afghanistan to strengthen the training of Afghan forces as a part of projecting stability over 2016. They also decided to establish training and counter terrorism centres in Iraq (Baghdad centre), as well as Tunisia and Libya in order to support the fight against the Islamic State. The Warsaw Summit of Heads of State and Government agreed that training Iraqi troops inside Iraq and Jordan was more effective against terrorism than sending their military forces against ISIS. [17] The alliance emphasized that collective security and 
territorial defence are once again NATO's core mission, so as a response to Russia's provocations, they agreed to send multinational troops to its neighbouring countries. [18] The head of States agreed that "go back 10 or 15 years and the changes that have unfolded are momentous. In the post-cold war and post-9/11 period, the idea had taken root that if NATO did not act out of area it would soon be out of business.” [19] President Obama summed things up by saying: "We're moving forward with the most significant reinforcement of collective defence any time since the Cold War”. [20]

\section{Conclusions}

NATO's attitude since the 9/11 events has changed in relation to terrorism, despite the fact that the fight against terrorism is not its core task. We are discussing the core responsibility of NATO on CT, but it is important to know that NATO has three core tasks, which include several responsibilities. It is argued that countering terrorism is already part of the Defence and Deterrence core task of NATO, even though it is not explicitly stated. Hence CT is already one of the core responsibilities of NATO, even if it is not a core task.

Having analysed the evolution of NATO strategies and the NATO Summits outcomes, it is clear that the most important commitments on the fight against terrorism appeared after the Warsaw and Wales Summits.

In connection with the fight against terrorism, the NATO Summit declarations do not include any specific military tasks for CT. However, the Allies emphasized continuing, enhancing their commitment to support the continuation of dialogue and cooperation with its partners. Specific military operations on countering terrorism continue as Operation Ocean Shield and Operation Active Endeavour.

Why can we not find any specific NATO's core military tasks on CT in these documents?

The answer is given by NATO in the Wales Summit Declaration which explains that the comprehensive political, civilian, economic, military approach is essential in crisis management, cooperative security and collective defence. The Wales Summit declaration states: "NATO has a role to play, including through our military cooperation with partners to build their capacity to face such threats, and through enhanced information sharing. Without prejudice to national legislation or responsibilities, the Alliance strives at all times to remain aware of the evolving threat from terrorism.” [16: para 79]

Based on my analysis, if NATO wishes to continue the fight against the terrorism, the following proposals need to be considered:

- to continue, and enhance training to build more effective security forces in a crisis like Iraq, Afghanistan, Libya etc. together with UN-EU NATO’s partners;

- to improve capabilities and technologies on DAT POW including IED and CBRN threats;

- focus more on domestic support for Collective Defence and Crisis Response operations together with the UN;

- to continue dialogue and cooperation between NATO and the EU;

- to rewrite and rethink Article 5 in order to determine how NATO could defeat and respond to the cyber and hybrid attacks in Collective Defence relations according to the actual Treaty.

A terrorist attack is an unexpected event, requiring proactive, co-ordinated reaction. Prevention requires robust investigative capacity and preparedness on both regional and local level. 
Imre POGÁCSÁS: What the NATO Alliance Is Currently Advocating and Delivering in the Counter...

In order to analyse how the terrorists are recruiting and facilitating within networks very powerful investigation tools are required with enhanced border security tracking and identification systems. NATO alone cannot achieve this, so those are the objectives that the UN Security Council Resolution 1373 (2001) sought to pursue to achieve following the terrorist attacks of $11^{\text {th }}$ September, 2001. [21: 2]

\section{References}

[1] HAVASI E.: A NATO válaszai a 21. századi kihívásokra: Harc a terrorizmus ellen. 2011. szeptember 27. old.biztonsagpolitika.hu/?id=16\&aid=1105\&title=a-nato (Downloaded: 27 10 2016)

[2] North Atlantic Military Committee Concept for Counter Terrorism MC 0472/1. www. nato.int/nato_static_fl2014/assets/pdf/topics_pdf/20160905_160905-mc-concept-ct.pdf (Downloaded: 412 2016)

[3] Chinese Proverbs with Pinyin and Original Translations. http://mychinesenow.com/chineseproverbs-translations-pinyin.html (Downloaded: 1804 2017)

[4] FBI: Terrorism. www.fbi.gov/investigate/terrorism (Downloaded: 1210 2016)

[5] ANDERSSSON, J. J., TARDY, T.: Hybrid: what's in a name? Brief-Issue, 32 (2015), 1-4. www.iss.europa.eu/uploads/media/Brief_32_Hybrid_warfare.pdf (Downloaded: 2311 2016)

[6] NATO 2010 Strategic Concept: Home. www.natolibguides.info/nsc (Downloaded: 1010 2016)

[7] Lisbon Summit Declaration. Issued by the Heads of State and Government participating in the meeting of the North Atlantic Council in Lisbon. 20 Nov. 2010. www.nato.int/cps/en/ natohq/official_texts_68828.htm (Downloaded: 1410 2016)

[8] Strategic Concept for the Defence and Security of the Members of the North Atlantic Treaty Organization. 19-20 November 2010. www.nato.int/strategic-concept/pdf/Strat_Concept_ web_en.pdf (Downloaded: 1210 2016)

[9] IKLODY G.: The New Strategic Concept and the Fight Against Terrorism: Challenges and Opportunities. Defence Against Terrorism Review, 32 (2010), 4-12.

[10] Prague Summit Declaration. www.nato.int/docu/pr/2002/p02-127e.htm (Downloaded: 1210 2016)

[11] The Istanbul Declaration Our security in a new era. Issued by the Heads of State and Government participating in the meeting of the North Atlantic Council in Istanbul on 28 June 2004. www.nato.int/docu/pr/2004/p04-097e.htm (Downloaded: 1210 2016)

[12] NATO boosts efforts in Afghanistan. www.nato.int/docu/update/2006/11-november/e1128a. htm (Downloaded: 1710 2016)

[13] Bucharest Summit takes NATO agenda forward. 03 Apr. 2008. www.nato.int/cps/en/natolive/ news_7195.htm (Downloaded: 1210 2016)

[14] Chicago Summit Declaration.www.nato.int/cps/en/natohq/official_texts_87593. htm?selectedLocale=en (Downloaded: 1810 2016)

[15] NATO Wales Summit 2014: outcomes. September 12, 2014. researchbriefings.parliament.uk/ ResearchBriefing/Summary/SN06981 (Downloaded: 2010 2016)

[16] Wales Summit Declaration. Issued by the Heads of State and Government participating in the meeting of the North Atlantic Council in Wales. 05 Sep. 2014. www.nato.int/cps/en/ natohq/official_texts_112964.htm\#terrorism (Downloaded: 2010 2016) 
Imre POGÁCSÁS: What the NATO Alliance Is Currently Advocating and Delivering in the Counter...

[17] Press conference by NATO Secretary General Jens Stoltenberg following the meeting of the North Atlantic Council at the level of Heads of State and Government on Projecting Stability. 09 Jul. 2016. www.nato.int/cps/en/natohq/opinions_133797. htm?selectedLocale=en (Downloaded: 2010 2016)

[18] Warsaw Summit Communiqué. Issued by the Heads of State and Government participating in the meeting of the North Atlantic Council in Warsaw 8-9 July 2016. 09 Jul. 2016. www. nato.int/cps/en/natohq/official_texts_133169.htm (Downloaded: 2210 2016)

[19] The Guardian view on the NATO summit. The Guardian, 10 July 2016. www.theguardian. com/commentisfree/2016/jul/10/the-guardian-view-on-the-nato-summit-a-refreshedalliance-for-troubled-times (Downloaded: 2003 2017)

[20] Press Conference by President Obama after NATO Summit. https://obamawhitehouse. archives.gov/the-press-office/2016/07/09/press-conference-president-obama-after-natosummit (Downloaded: 1903 2017)

[21] INTERPOL's capacity in Emergency Responses in the Aftermath of Terrorist Incidents. New York: INTERPOL, 2015. www.un.org/en/sc/ctc/docs/2015/statement_INTERPOL_open_ briefing_emergencies_16_June_2015.pdf (Downloaded: 2510 2016) 